\title{
Peran Pelatihan Mental Dalam Meningkatkan Kepercayaan Diri Atlet Renang Sekolah Ragunan
}

\author{
Juriahn $^{a}$, Kurnia Tahki ${ }^{b}$ \\ Universitas Negeri Jakarta, Jl. Pemuda no 10 Rawamangun, Jakarta 13220
}

*Corresponding author: yana.djuhriansyah@gmail.com

\section{A RTICLE INFO}

Article history:

Received 13 April 2017

Received in revised form 20 April 2017

Accepted 29 April 2017

Keywords:

Mental training, sport confidence

\begin{abstract}
A B S T R A C T
Sport confidence is important psychology's aspect for athletes to be successful in their performance. SMP/SMA Ragunan' swimmers are junior talent athletes to accelerate in sport champion. This research discuss about the role of mental training in enhancing sport confidence of SMP/SMA Ragunan's swimmers. This is a qualitative research with pre-experiment design. The result of this research showed that mental training have actively role in enhancing sport confidence of SMP/SMA Ragunan's swimmers. Relaxation and visualization training plays the best role in enhancing sport confidence. Based on result of this research suggest that Ragunan's swimmers have to continue mental training until they get positive effect in their performance. Besides, sport needs more sport psychologist in the future to give mental training and education programe in another kinds of sport.
\end{abstract}

\section{Pendahuluan}

Salah satu tujuan pembinaan olahraga di Indonesia adalah untuk meningkatkan prestasi. Untuk meningkatkan prestasi olahraga di Indonesia perlu diadakan pembibitan, seperti pembinaan kelompok umur di setiap cabang olahraga. Jenjang kelompok umur diharapkan dapat menjadi wadah pembinaan agar regenerasi terus bergulir. Dengan demikian, sewaktu-waktu para atlet seniornya sudah tidak dapat berprestasi lagi, maka atlet juniornya dapat menggantikan dan menjadi penerus perjuangan dan pencapaian prestasi yang lebih baik lagi.

Pencapaian prestasi olahraga yang optimal tidaklah mudah, diperlukan usaha dan latihan yang maksimal dan disiplin yang tinggi. Oleh karena itu, pada tahun 1977 pemerintah DKI Jakarta mendirikan Sekolah Khusus Olahragawan SMP/SMA Negeri Ragunan, selanjutnya disebut Sekolah Ragunan, dimana siswa sekolah tersebut adalah atlet pilihan dari berbagai daerah.

Salah satu cabang olahraga yang ditekuni oleh atlet Sekolah Ragunan adalah renang. Renang merupakan cabang olahraga yang selalu dipertandingan pada setiap kegiatan olahraga multi-event. Renang juga merupakan cabang olahraga yang memiliki nomor terbanyak untuk dipertandingkan, sehingga menjadi olahraga yang sangat potensial untuk bisa memperoleh medali sebanyak-banyaknya.

Jumlah atlet renang Ragunan dari tahun ke tahun relatif stabil, antara 13 sampai 16 orang setiap tahunnya. Menurut pelatih, prestasi atlet renang Ragunan saat ini masih perlu ditingkatkan. Beberapa perenang masih tidak dapat menampilkan atau meningkatkan best-time pribadinya pada saat pertandingan. Catatan waktu yang mereka buat pada saat pertandingan tidak sama atau tidak lebih baik dibandingkan pada saat pertandingan (Wawancara dengan pelatih renang Ragunan, Desember 2011).

Performa yang tidak optimal pada atlet renang Sekolah Ragunan ini perlu mendapatkan perhatian, karena performa menjadi ukuran untuk mengevaluasi peningkatan prestasi seorang atlet dalam dunia olahraga. Menurut Allport dalam Deaux, Dane, Wrightsman, Lawrence, dan
Siegelman (1993), performa individu dalam melakukan suatu hal dipengaruhi oleh kehadiran orang lain atau dikenal dengan social influence. Kehadiran atau perilaku orang lain dapat meningkatkan kualitas performa individu (disebut social facilitation) atau dapat menurunkan performa individu (disebut social impairment). Lebih lanjut dikatakan bahwa dampak negatif dari pengaruh lingkungan lebih dirasakan oleh individu dengan self-efficacy yang rendah. Jenings dan Morris dalam Baron dan Bryne (1994) menyatakan bahwa seseorang yang memiliki self-efficacy yang rendah cenderung memiliki kecemasan yang tinggi dalam interaksi sosial.

Sebagaimana diungkapkan oleh Satiadarma (2000) bahwa dalam beberapa situasi tertentu bisa terjadi dimana seorang atlet yang telah memperoleh prestasi yang baik selama latihan namun saat pertandingan ia tidak mampu tampil dengan baik. Efektifitas gerakannya yang selama latihan tampil dengan baik seolah-olah pudar begitu saja ketika bertanding. Kecepatan gerakannya menjadi menurun, sebaliknya ia tampil sangat kaku. Atlet ini mungkin menghadapi masalah kurang percaya diri. Menurut Weinberg dan Gould (1995) atlet yang kurang percaya diri (lack of confidence) cenderung merasa cemas, kurang memusatkan diri pada kekuatan yang dimilikinya, dan konsentrasinya terhadap tugas yang sedang dikerjakan mudah terganggu.

Beberapa atlet renang Ragunan sendiri menyatakan bahwa saat ini mereka memang masih kurang percaya diri ketika menghadapi pertandingan. Meskipun sudah giat berlatih, namun mereka sering merasa kurang yakin terhadap kemampuan atau teknik yang dimiliki. Atlet belum mampu mengatur kecepatan renang (pace) secara optimal dan konsentrasi mereka mudah terganggu saat pertandingan. Selain itu, atlet juga masih sering merasa kurang mampu bersaing dengan lawan yang memiliki catatan waktu lebih baik dan kurang yakin dirinya mampu mengatasi tekanan saat pertandingan berlangsung. Kondisi-kondisi yang dirasakan oleh atlet tersebut membuat performance mereka tidak optimal pada saat pertandingan (Wawancara dengan lima atlet renang Sekolah Ragunan, Desember 2011).

Berdasarkan analisa di atas, maka dapat disimpulkan bahwa sumber masalah yang terjadi pada atlet renang Sekolah Ragunan adalah 
kurangnya kepercayaan diri, terutama dalam menghadapi pertandingan. Oleh karena itu, perlu diusahakan cara yang tepat untuk meningkatkan kepercayaan diri atlet renang Sekolah Ragunan. Melalui penelitian ini, akan dilakukan intervensi yang dapat meningkatkan kepercayaan diri atlet renang Sekolah Ragunan.

\subsection{Kepercayaan Diri}

Kepercayaan diri memiliki kaitan yang erat dengan self-efficacy. Bandura (1997) menyatakan self-efficacy adalah penilaian mengenai seberapa baik seseorang dapat menampilkan perilaku yang dibutuhkan untuk mengatasi situasi atau tugas tertentu. Dalam dunia olahraga istilah self-efficacy lebih dikenal dengan sebutan sport-confidence. Vealey (1986) mendefinisikan sport-confidence sebagai keyakinan individu mengenai kemampuannya untuk berhasil dalam olahraga. Menurut Singer (dalam Setyobroto, 2005), percaya diri adalah perasaan bahwa dirinya memiliki kemampuan untuk melakukan apa yang harus dilakukan. Berdasarkan beberapa pengertian di atas, maka kepercayaan diri diartikan sebagai tingkat keyakinan individu terhadap kemampuannya untuk berhasil pada situasi olahraga tertentu.

Berdasarkan model sport-confidence yang dikembangkannya, Vealey dan Knight (dalam Horn, 2008) mengidentifikasi tiga dimensi dalam sport-confidence:

- Physical skills and Training (Latihan dan Keterampilan Fisik), merupakan tingkat keyakinan atau kepercayaan atlet bahwa dirinya memiliki kemahiran dan keterampilan fisik yang dibutuhkan untuk mencapai kesuksesan.

- Cognitive Efficiency (Efisiensi Kognitif), merupakan tingkat keyakinan atau kepercayaan atlet bahwa dirinya mampu memfokuskan diri, mampu memelihara konsentrasi dan membuat keputusan untuk mencapai kesuksesan.

- Resilience (Keuletan), merupakan tingkat keyakinan atau kepercayaan atlet bahwa dirinya mampu memfokuskan diri kembali setelah berbuat kesalahan, mampu segera bangkit setelah penampilan yang buruk, mampu mengatasi keraguan-masalah dan penurunan untuk mencapai kesuksesan.

Alat ukur sport-confidence sudah cukup banyak dikembangkan di Amerika Serikat oleh Vealey, diantaranya adalah the Trait SportConfidence Inventory (TSCI), SSCQ (Sources of Sport-Confidence Quetionere), The Carolina Sport Confodence Inventory (CSCI), dan the State Sport-Confidence Inventory (SSCI) (Feltz, 2008).

Bandura dalam Satiadarma (2000) mengemukakan bahwa keyakinan atau kepercayaan diri seseorang bersumber pada empat hal utama yaitu : hasil yang pernah dicapai, model perilaku, persuasi verbal, dan gugahan emosional. Keempat sumber ini yang kemudian membentuk kepercayaan diri, untuk selanjutnya mempengaruhi performa olahraga.

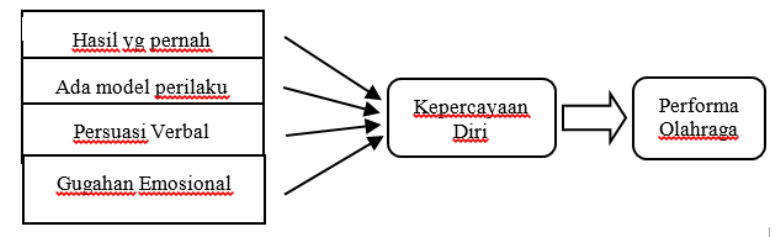

Gambar 1 : Hubungan sumber kepercayaan diri dan performa olahraga

Hasil yang pernah dicapai seorang atlet berpengaruh cukup besar pada keyakinan dirinya. Jika ia sering berhasil, ia akan memiliki keyakinan yang lebih besar. Contoh perilaku yang harus ditampilkan atlet dapat diberikan oleh pelatih melalui pemutaran film atau mendatangkan pakar cabang olahraga tertentu. Belajar dengan mencontoh harus memenuhi empat syarat yaitu : ada perhatian, ada pengulangan, diterapkan dalam gerak motorik, dan motivasi. Persuasi verbal adalah teknik untuk membangkitkan semangat individu yang kerap digunakan pelatih dan disampaikan secara verbal. Adapun gugahan emosional adalah hasil persepsi seseorang terhadap suatu keadaan tertentu.

Berdasarkan penjelasan di atas, maka sumber atau faktor yang mempengaruhi kepercayaan diri ada yang berasal dari luar diri atlet dan dari dalam diri atlet sendiri. Hasil yang diperoleh, persuasi verbal, dan model perilaku adalah faktor yang bersifat eksternal. Sedangkan gugahan lebih bersifat internal, meskipun kemungkinan tetap ada pengaruh eksternal.

Dalam cabang olahraga renang, hasil yang diperoleh adalah catatan waktu perenang dari waktu ke waktu. Untuk mendapatkan feedback catatan waktu, atlet harus sering mengikuti event pertandingan. Sementara event pertandingan renang yang dapat diikuti oleh atlet renang Sekolah Ragunan masih terbatas jumlahnya. Sementara untuk memberikan feedback catatan waktu latihan, pelatih perlu memiliki dokumentasi yang lengkap. Hal ini tampak masih sulit diterapkan mengingat terbatasnya jumlah pelatih yang menangani atlet renang Ragunan. Bergabungnya sejumlah atlet renang PPLP (Pusat Pendidikan dan Latihan Pelajar) di Ragunan, menambah jumlah atlet yang berlatih bersama saat ini hingga 24 orang dengan tiga orang pelatih.

Saat ini juga belum ada model perilaku yang benar-benar dapat menjadi contoh bagi atlet renang Ragunan. Perenang senior Ragunan yang berhasil di SEA Games sudah tidak berlatih bersama mereka, bahkan sudah berganti cabang olahraga dari renang menjadi fins swimming. Sehingga hal ini pun tampaknya tidak dapat diterapkan untuk meningkatkan kepercayaan diri atlet renang Ragunan.

Sebagaimana cabang olahraga lainnya, perenang baru akan memperoleh penguatan atau persuasi verbal jika mampu menunjukkan kemampuan fisik dan teknik yang lebih baik atau benar. Atlet renang sekolah Ragunan adalah atlet junior yang tentunya masih membutuhkan banyak perbaikan baik secara fisik maupun teknik. Pelatih tidak dapat memberikan pujian jika perenang tidak menunjukkan perbaikan yang diharapkan. Mempertimbangkan hal tersebut, tentunya pemberian persuasi verbal ini menjadi sulit untuk dikontrol.

Gugahan emosional menunjukkan kondisi internal atlet yang sebenarnya lebih dapat dikontrol karena melibatkan individu atlet yang bersangkutan. Atlet harus mampu mengatur gugahannya agar muncul sesuai dengan tuntutan lingkungan yang dihadapi. Gugahan emosional ini dapat dikontrol dengan cara atau latihan mental tertentu. Menurut Vealey (dalam Weinberg dan Gould, 1995), empat latihan mental yang dapat diberikan kepada atlet dalam bentuk pendidikan dan latihan, yaitu : goalsetting, physical relaxation, thought/attention control, dan imagery.

Berdasarkan pertimbangan tersebut di atas, peneliti melihat kemungkinan mengendalikan kepercayaan diri atlet renang Sekolah Ragunan yang paling memungkinkan adalah dengan mengendalikan gugahan atlet melalui pelatihan mental. Pelatihan mental yang diberikan terdiri dari : penetapan sasaran, relaksasi, latihan konsentrasi, dan visualisasi. Melalui penelitian ini diharapkan dapat diketahui peran latihan mental untuk meningkatkan kepercayaan diri atlet renang Sekolah Ragunan, sekaligus mengetahui bentuk latihan mental mana yang paling berperan untuk meningkatkan kepercayaan diri atlet renang Sekolah Ragunan.

\subsection{Pelatihan Mental}

Menurut Gunarsa, Soekasah, dan Satiadarma (1996), latihan mental didefinisikan sebagai :

"a systematic, regular and longterm training to detect and develop resources and to learn to control performance, behavior, emotions, moods, attitudes, strategies and bodily processes".

Tujuan latihan mental adalah agar atlet dapat mengontrol pikiran, emosi, dan perilakunya dengan lebih baik selama ia menampilkan performa olahraganya. Lebih lanjut para ahli menyatakan bahwa latihan mental bertujuan agar atlet memiliki ketahanan mental, yaitu pendirian yang tak tergoyahkan untuk mencapai tujuan meskipun berada di bawah tekanan (Loehr, 1982).

Berdasarkan pengertian tersebut, maka pelatihan mental diartikan 
sebagai latihan yang dilakukan atlet untuk meningkatkan fungsi berpikirnya agar dapat mengendalikan tubuh dan tindakannya. Pelatihan mental merupakan latihan yang dilakukan untuk memperoleh ketahanan mental, sehingga dapat mencapai prestasi yang prima dalam setiap pertandingan.

Menurut Weinberg dan Gould (1995), tahapan atau fase latihan mental terbagi menjadi tiga, yaitu :

- Tahap pendidikan, Tahap ini merupakan tahap pemberian penjelasan mengenai latihan mental, agar atlet merasa familiar terhadap keterampilan mental. Tahap ini juga bertujuan agar atlet menyadari betapa pentingnya mempelajari latihan mental. Pada tahap ini dapat didahului dengan diskusi tentang pentingnya mental, berapa kali latihan mental sudah dilakukan selama ini, serta contoh-contoh kasus yang terjadi dalam olahraga.

- Tahap akuisisi atau perolehan, Tahap ini berfokus pada strategi dan teknis pelaksanaan. Tahap ini dilakukan untuk mengetahui keunikan atau kondisi tiap individu. Pada tahap ini, diharapkan dapat diketahui bagaimana kemampuan individu dan apa yang menjadi kebutuhannya. Beberapa bentuk assessment dapat dilakukan pada tahapan ini.

- Tahap Pelatihan, Tahap ini merupakan tahap akhir atau tahap pelatihan itu sendiri. Tahap ini memiliki beberapa tujuan, yaitu : mencapai otomatisasi, mengajarkan integrasi keterampilan psikologis ke dalam situasi atau gerakan, dan mensimulasikan pada situasi kompetisi.

Menurut Vealey (dalam Weinberg dan Gould, 1995), keterampilan psikologis atau mental yang dapat dikembangkan melalui metode pendidikan dan latihan ada empat, yaitu : goal-setting, physical relaxation, thought/attention control, dan imagery.

a) Goal-setting

Goal-setting atau penetapan sasaran merupakan dasar dari latihan mental. Penetapan sasaran perlu dilakukan agar atlet memiliki arah yang harus dituju. Sasaran tersebut dapat berupa sasaran jangka panjang, menengah, dan jangka pendek (Nasution, 2009).

Dalam menentukan sasaran, terdapat empat prinsip utama (Deputi Bidang Peningkatan Prestasi Olahraga, 2011) yaitu :

- Difficulty, goal yang sulit akan meningkatkan performa dibandingkan dengan goal yang mudah

- Specificity, goal yang spesifik akan lebih efektif dibandingkan dengan goal yang subjektif atau tidak ada goal.

- Acceptance, goal akan lebih efektif jika ditetapkan atau dibuat sendiri oleh atlet.

- Feedback, goal tidak akan efektif jika tidak diberikan umpan balik.

\section{b) Physical Relaxation}

Bentuk latihan mental lainnya adalah relaksasi. Relaksasi merupakan prosedur penting dalam program latihan mental. Relaksasi juga merupakan prosedur awal yang harus dilaksanakan dalam program latihan mental (Weinberg and Gould, 1995). Hal ini dikarenakan dalam kondisi relaks seseorang lebih terbuka peluangnya untuk memusatkan perhatian.

Selain itu, Stevens dan Lane (2001) menjelaskan bahwa prosedur relaksasi dapat membuat seseorang lebih mampu mengendalikan suasana hatinya, sehingga atlet tersebut tidak mudah dipengaruhi oleh gangguangangguan emosional sesaat yang mungkin muncul dari dalam dirinya sendiri maupuan dari luar dirinya. Apabila atlet menjalani prosedur relaksasi dengan baik, hal itu sendiri sudah cukup efektif untuk meredakan kecemasan yang dialami, karenanya hal tersebut membuka peluang lebih besar bagi atlet untuk dapat mengikuti latihan mental dengan baik (Fletcher dan Hanton, 2001). Kondisi relaks menunjukkan bahwa fungsi kognitif mereka menjadi lebih baik, kondisi mereka menjadi lebih tenang dan prestasi mereka mengalami peningkatan.

Relaksasi yang digunakan dalam penelitian ini adalah relaksasi otot progresif dasar (progressive muscular relaxation). Prosedur relaksasi ini pertama kali dikenalkan oleh Lazarus dan Paul (Goldfried dan Davidson, 1976). Kemudian dikembangkan oleh Jacobson untuk menolong atlet mengatasi tekanan dan kecemasan (Deputi Bidang Peningkatan Prestasi Olahraga, 2011). Tujuannya adalah agar atlet dapat mengontrol tekanan dalam setiap kelompok otot utama di dalam tubuh. Otot yang dilatih antara lain otot tangan, wajah, leher, bahu, perut, dan kaki (Rushal, 2008)

\section{c) Thought/attention Control}

Konsentrasi merupakan suatu keadaan dimana kesadaran seeorang tertuju pada suatu objek tertentu dalam waktu tertentu (Nasution, 2009). Sementara Weinberg dan Gould (1995) membatasi konsentrasi sebagai : 1) kemampuan seseorang untuk memusatkan perhatian atau fokus kepada isyarat tertentu yang sesuai dengan tugasnya; dan 2) mempertahankan fokus perhatian tersebut.

Komponen utama dari konsentrasi adalah kemampuan untuk memusatkan perhatian pada suatu objek atau hal tertentu tanpa terganggu oleh stimulus internal (gangguan dari dalam diri yang berupa sensoris ataupun pikiran seperti rasa lelah, cemas, dan sebagainya) maupun stimulus eksternal yang tidak relevan (gangguan dari luar diri seperti sorakan penonton, keputusan wasit yang dianggap merugikan diri, dan sebagainya). Sejalan dengan komponen utama tersebut, maka tujuan latihan konsentrasi adalah agar atlet dapat memusatkan perhatian dan pikirannya terhadap sesuatu yang ia lakukan tanpa terpengaruh oleh pikiran atau hal-hal yang terjadi di sekitarnya (Nasution, 2009).

\section{d) Imagery atau Visualization}

Imagery atau visualisasi merupakan bentuk kreasi mental yang dilakukan secara sadar dan disengaja dan bertujuan untuk membentuk persepsi sesuatu dengan jalan membentuk imaji kreatif di dalam benak seseorang (Fanning, 1988). Melalui proses mental kreatif ini, seseorang dapat mengubah persepsinya terhadap sesuatu karena ia membentuk imaji suatu keadaan dalam berbagai bingkai persepsi, atau melihat suatu keadaan tertentu dari berbagai sudut pandang.

Dalam konsep latihan mental dalam olahraga, visualisasi juga sering disebut sebagai mental rehearsal atau juga imagery process (Porter dan Foster, 1990, p.17). Porter dan Foster menyatakan : "The reason visualization/imagery works is ... you are physiologically creating neural patterns in your brain, just as if your body had done the activity. These patterns are like small tracks engraved in the brain cells. It has been demonstrated that athletes who have never performed a certain routine or move can after a few weeks of specific visualization practice perform the move. As in physical practice, mental practice makes perfect too".

Dalam proses visualisasi seorang individu melakukan latihan mental dengan menggunakan kondisi precues (pra-isyarat). Kondisi pra-isyarat ini melibatkan aspek konsentrasi dan dilandasi oleh tiga hal utama. Pertama, hal yang divisualkan harus terlebih dahulu tertanam dalam ingatan seseorang. Kedua, untuk memfungsikan perilaku sesuai dengan pra-isyarat seseorang harus memusatkan perhatian secara sungguhsungguh pada sasaran perilaku, jika hal ini tidak dilakukan maka arah perilaku mungkin akan menyimpang. Ketiga, perhatian harus berlangsung terus di dalam area pra-isyarat hingga tercapainya sasaran perilaku (Eversheim dan Block, 2002).

Shone (1984) mengemukakan bahwa imaji yang muncul di dalam proses visualisasi merupakan hal yang amat penting karena imaji tersebut memberi pengaruh tidak hanya pada psikis tetapi juga pada ketubuhan seeorang. Sejalan dengan Eversheim dan Block (2002) yang menjelaskan bahwa selama berlangsungnya perilaku ke arah sasaran, kondisi praisyarat atau visualisasi sasaran harus tetap dipertahankan. Menurut Fanning (1988), jika hal ini tidak dilandasi oleh persiapan yang matang serta kesiapan yang baik, visualisasi tersebut akan tinggal sebagai suatu fantasi atau angan-angan belaka.

Metode visualisasi merupakan metode yang menyatukan aspek kognitif dan perilaku. Informasi yang dimiliki seseorang dan gerakan yang dilakukan oleh orang terebut merupakan dua hal yang berpasangan secara 
erat (Savelbergh dan Kamp, 2000). Oleh karena itu, mereka menekankan pentingnya kekhasan latihan visualisasi bagi masing-masing cabang olahraga, bahkan nomor-nomor pertandingan yang bersifat spesifik atau individual.

Visualisasi yang digunakan dalam penelitian ini adalah visualisasi terpandu, yang pada dasarnya menggabungkan antara visualisasi reseptif dan visualisasi terprogram. Visualisasi reseptif mengarahkan individu untuk mengeksplorasi alam ketidaksadaran. Sementara visualisasi terprogram mengarahkan seseorang agar bertindak ke arah sasaran tertentu dan memperbaiki performansi atau penampilan (Fanning dalam Satiadarma, 2006). Karena mempertimbangkan bahwa visualisasi melibatkan proses kognitif, maka dalam penelitian ini juga dilakukan tes intelegensi dengan menggunakan skala CFIT-3A.

Bhamri, Dhillon, dan Sahni (2005) telah melakukan penelitian berupa intervensi psikologis terhadap sejumlah pemain tenis meja berusia 12-17 tahun. Beberapa latihan mental diberikan untuk mengetahui bentuk latihan mental yang memiliki efek paling tinggi terhadap ketahanan mental atlet. Hasil penelitian menunjukkan bahwa atlet yang diberikan latihan relaksasi dan imagery menunjukkan peningkatan ketahanan mental yang paling tinggi, salah satunya peningkatan dalam kepercayaan diri.

Berbagai penelitian menunjukkan bahwa latihan imagery efektif untuk meningkatkan performa, meskipun pengaruhnya bersifat tidak langsung. Hasil penelitian menemukan bahwa imagery secara konsisten berhasil meningkatkan self-efficacy, dan akhirnya meningkatkan performa (Howe, 1991).

Michael Phelps, adalah perenang dunia asal Amerika yang selalu melakukan latihan relaksasi dan visualisasi sebelum bertanding. Latihan mental tersebut membantunya merasakan gerakan dan kecepatan renang yang sempurna ketika ia sudah benar-benar berada di kolam pertandingan. Perenang spesialisasi gaya kupu-kupu ini menjadi peraih medali emas terbanyak di cabang renang sepanjang Olimpiade, yaitu sebanyak 16 medali (Townsend, 2005).

\section{Metode}

Penelitian ini adalah penelitian kualitatif, dengan desain penelitian pra-eksperimen karena tidak adanya kelompok kontrol. Hal ini mempertimbangkan bahwa jumlah atlet renang Sekolah Ragunan yang terbatas. Menurut Stelter (2003), pendekatan kualitatif adalah metode yang tepat untuk dikembangkan sebagai pendekatan baru dalam psikologi olahraga dan latihan. Hal ini dikarenakan pengalaman yang melibatkan aktivitas dan tubuh seperti atlet bersifat sangat individual (individual differences). Selain memiliki karakteristik yang berbeda-beda, pengalaman atlet juga dipengaruhi oleh situasi spesifik yang sedang dihadapinya. Sementara beberapa data kuantitatif dijadikan sebagai data tambahan atau data pendukung.

Subjek atau disebut informan dalam penelitian ini yaitu tujuh orang atlet renang Sekolah Ragunan yang memiliki kriteria sebagai berikut : berusia 12-18 tahun, masih aktif berlatih dan menjalani program latihan yang sama, tercatat sebagai siswa SMP/SMA Negeri Ragunan, penampilan saat bertanding tidak optimal (berdasarkan keterangan pelatih), dan kepercayaan diri rendah (berdasarkan skor kuesioner SSCI).

Pengumpulan data utama dalam penelitian ini dilakukan dengan cara wawancara. Sementara data tambahan dilakukan dengan menggunakan alat ukur atau kuesioner kepercayaan diri. Sedangkan teknik analisis data dilakukan berdasarkan data-data yang dikumpulkan. Pengolahan data kualitatif atau wawancara dilakukan dengan cara membuat kategorisasi jawaban informan. Sementara pengolahan data kuantitatif dilakukan dengan menguji validitas dan reliabilitas dari kuesioner kepercayaan diri.

Hasil uji coba alat ukur kepercayaan diri atlet renang selama bulan April 2012, menunjukkan bahwa alat ukur tersebut memiliki reliabilitas sebesar $r=0,921$. Sedangkan validitasnya juga tergolong baik berkisar antara 0,405 sampai 0,829

Studi awal dalam penelitian ini dibagi menjadi dua, yaitu tahap pendidikan dan tahap akuisisi. Secara umum, penelitian pada tahap pendidikan dianggap berhasil karena dapat memotivasi dan mendorong kesediaan tujuh dari tujuh perenang yang memenuhi kriteria sebagai informan untuk mengikuti tahap selanjutnya.

Pada tahap akuisisi, peneliti berhasil mengidentifikasi empat keterampilan mental yang dimiliki tujuh perenang yaitu meliputi kemampuan: goal-setting, relaksasi, konsentrasi, dan visualisasi. Semua perenang memiliki keterampilan mental yang tergolong cukup dan kurang. Hal ini menunjukkan sekaligus menjadi pertimbangan bahwa intervensi yang dilakukan harus meliputi keempat teknik keterampilan mental, yaitu : goal-setting, relaksasi, konsentrasi, dan visualisasi. Pada tahap akuisisi ini juga digunakan tes intelegensi dengan menggunakan CFIT-3A skala Cattel. Hasilnya menunjukkan bahwa IQ perenang berkisar antara 93-106 (average). Hal ini menjadi pertimbangan bahwa pelatihan mental kemungkinan tidak mengalami hambatan, terutama pelatihan visualisasi yang membutuhkan proses kognitif.

Program intervensi ini terdiri dari empat bentuk atau teknik pelatihan mental, yaitu : goal-setting, relaksasi, konsentrasi, dan visualisasi. Dalam cabang olahraga renang, penetapan sasaran atau goal-setting sangat penting. Sebagai cabang olahraga terukur, sasaran atau target adalah catatan waktu yang bersifat nyata. Perenang dianggap dapat mencapai target jika ia dapat mempertajam catatan best-time pribadinya secara konsisten dari waktu ke waktu. Penetapan sasaran akan membuat perenang tertantang dan berusaha untuk mencapainya.

Latihan relaksasi adalah prosedur penting dan awal dalam pelatihan mental. Sebagaimana di cabang olahraga lain, relaksasi juga dibutuhkan dalam cabang olahraga renang. Perenang perlu belajar merasa rileks, sehingga kondisi mereka lebih tenang dan lebih berpeluang untuk memusatkan perhatian pada tugas yang dihadapi.

Latihan konsentrasi merupakan latihan yang dilakukan agar atlet dapat mempertahankan fokus atau perhatiannya pada suatu objek atau hal tertentu tanpa terganggu oleh stimulus internal (seperti perasaan lelah) maupun stimulus eksternal yang tidak relevan (seperti sorakan penonton). Latihan ini juga sangat dibutuhkan oleh perenang, di mana mereka harus mampu berkonsentrasi pada gerakan renang dari mulai start sampai finish. Latihan konsentrasi juga dimaksudkan sebagai persiapan sebelum perenang memulai atau melakukan latihan visualisasi.

Pada dasarnya, latihan visualisasi merupakan latihan yang menyatukan aspek kognitif dan perilaku. Dengan pemberian instruksi gerakan, membuat perenang memiliki informasi tentang gerakan renang dan terdorong untuk melakukan gerakan tersebut pada situasi yang sesungguhnya. Misalnya: membayangkan gerakan tarikan tangan dan tendangan kaki, gerakan saat start-pembalikan-finish, atau membayangkan kecepatan renang yang diinginkan.

\section{Hasil dan diskusi}

Setelah pelatihan, enam dari ketujuh perenang mengalami peningkatan keterampilan goal-setting. Informan $\mathrm{G}$ adalah informan yang keterampilan goal-settingnya masih kurang. Selain itu, tujuh dari ketujuh perenang mengalami peningkatan pada tiga keterampilan mental lainnya, yaitu : relaksasi, konsentrasi, dan visualisasi.

Selain itu, menurut empat informan (A, B, F, dan G), latihan relaksasi adalah latihan yang paling berpengaruh untuk meningkatkan kepercayaan dirinya. Bagi A, kecemasannya menurun setelah tubuhnya merasa rileks. Kecemasan tersebut kemudian berganti menjadi rasa percaya diri. Bagi B, kondisi rileks setelah relaksasi membuat ia lebih fokus, gerakan dan gaya renangya pun menjadi lebih terkontrol. Menurut F, kondisi tubuhnya setelah relaksasi menjadi lebih siap untuk dipakai dalam gerakan renang, dan hal ini membuatnya merasa percaya diri. Sementara bagi G, kondisi 
rileks setelah relaksasi membuat ia tidak lagi memiliki banyak pikiran yang mengganggu.

Sedangkan tiga informan lainnya (C, D, dan E) merasa bahwa latihan visualisasi adalah latihan yang paling berpengaruh untuk meningkatkan kepercayaan dirinya. Bagi C, visualisasi membuatnya menjadi lebih mudah untuk mengatur kecepatan. Hal ini sangat membantu $\mathrm{C}$ sebagai perenang jarak jauh 1500 meter, dan membuatnya lebih percaya diri. Bagi $\mathrm{D}$, latihan visualisasi membuat ia mampu mengatur tarikan tangan dengan lebih baik. Ia pun merasa berenang lebih enak dan lebih percaya diri. Sementara bagi E, visualisasi membuatnya lebih mudah melakukan gerakan ketika berenang pada situasi yang sebenarnya.

Perubahan tingkat kepercayaan diri informan dalam penelitian ini ditinjau dari tiga dimensi kepercayaan diri, yaitu : dimensi latihan dan keterampilan fisik, dimensi efisiensi kognitif, dan dimensi keuletan. Ditinjau dari dimensi kepercayaan diri yang pertama, enam dari ketujuh perenang yakin dengan latihan dan keterampilan fisik yang dimiliki. Informan $\mathrm{G}$ adalah satu perenang yang belum yakin dengan teknik yang dimiliki.

Peningkatan dimensi kepercayaan diri kedua yang paling menonjol bahwa tujuh dari ketujuh perenang sudah merasa yakin dapat mencapai target yang ditentukan sendiri. Selain itu, baru empat dari ketujuh perenang yang mampu mengatur kecepatan renangnya.

Peningkatan dimensi kepercayaan diri yang paling menonjol bahwa tujuh dari ketujuh perenang sudah merasa yakin mampu bersaing dengan lawan pada saat pertandingan. Namun hanya dua dari ketujuh perenang yang merasa yakin bahwa dirinya mampu bertanding di bawah tekanan.

Berdasarkan kuesioner kepercayaan diri, diketahui bahwa terjadi perubahan tingkat kepercayaan diri sebelum dan setelah intervensi. Hasil uji beda statistik menunjukkan bahwa perubahan skor kepercayaan diri informan sebelum dan setelah intervensi adalah signifikan dengan nilai signifikansi $\mathrm{t}=0,018<0,05$.

Berdasarkan hasil Kejuaraan Nasional Renang bulan Mei 2012, diketahui bahwa setelah mengikuti pelatihan mental dua informan mengalami perbaikan best-time di nomor utama, tiga informan mengalami perbaikan best-time di nomor yang lain, dan dua informan belum berhasil memperbaiki best-time. Namun begitu, semua informan mengakui bahwa mereka lebih enak saat bertanding setelah mengikuti pelatihan mental. Perenang merasa lebih bersemangat namun mampu mengendalikan diri agar tetap tenang, rileks, dan konsentrasi.

\section{Diskusi}

Pelatihan mental belum banyak dilakukan secara khusus oleh pelatih untuk mendampingi latihan fisik pada atlet selama ini. Padahal latihan mental dalam olahraga harus dianggap sama pentingnya dengan latihan fisik (Gunarsa, Soekasah, Satiadarma, 1986). Intervensi pelatihan mental yang dilakukan dalam penelitian ini berusaha untuk memberikan sumbangan bagi perkembangan olahraga khususnya dalam rangka meningkatkan kepercayaan diri atlet renang Ragunan.

Setelah pelaksanaan intervensi atau selesai tahap pelatihan, enam dari tujuh perenang mengalami peningkatan keterampilan goal-setting. Satu perenang yang masih sulit dalam menentukan target ternyata adalah $\mathrm{G}$ perenang yang baru satu tahun terakhir bergabung latihan di Ragunan. Sejak itulah ia baru mulai mengikuti berbagai pertandingan, sehingga keterampilannya dalam menentukan target untuk dirinya sendiri saat ini masih kurang memadai. Namun begitu, semua perenang mengalami peningkatan tiga keterampilan keterampilan mental lainnya, yaitu : relaksasi, konsentrasi, dan visualisasi.

Ditinjau dari dimensi kepercayaan diri yang pertama, enam dari tujuh perenang yakin dengan latihan dan keterampilan fisik yang dimiliki. Satu perenang yang belum yakin dengan keterampilan atau teknik yang dimiliki adalah $\mathrm{G}$ perenang yang baru satu tahun terakhir bergabung latihan di Ragunan. Menurut pelatih, teknik dan gaya yang dimiliki G saat ini memang sedang diperbaiki dan diasah lebih lanjut. Kemungkinan hal ini yang membuat ia merasa belum yakin sepenuhnya dengan keterampilan fisik atau teknik renang yang dimiliki. Berdasarkan dimensi kepercayaan diri yang kedua, tujuh dari tujuh perenang sudah merasa yakin mampu mencapai target yang ditentukan sendiri. Sedangkan ditinjau dari dimensi kepercayaan diri yang ketiga, tujuh dari tujuh perenang sudah merasa yakin mampu bersaing dengan lawan pada saat pertandingan.

Penelitian ini membatasi pada peran pelatihan mental dalam meningkatkan kepercayaan diri atlet renang Ragunan. Hasil penelitian menunjukkan bahwa peningkatan keterampilan mental diikuti oleh peningkatan kepercayaan diri semua perenang. Peningkatan kepercayaan diri yang terjadi pada atlet renang Ragunan saat ini belum terlihat langsung dampaknya terhadap performa. Meskipun berdasarkan teori, peningkatan kepercayaan diri biasanya juga diikuti oleh peningkatan performa (Feltz, 1984; Weinberg dan Gould, 1995; Satiadarma, 2000) Oleh karena itu, latihan mental harus dilakukan terus oleh atlet agar memiliki dampak positif terhadap peningkatan performa atau penajaman dalam best-time (catatan waktu terbaik). Weinberg dan Gould (1995) mengatakan bahwa latihan mental memang seharusnya terus dilakukan sepanjang atlet menjalankan aktifitas cabang olahraganya. Selain itu, aspek mental adalah salah satu aspek pendukung keberhasilan dalam performa olahraga. Masih terdapat aspek lain yang diperlukan untuk mendukung keberhasilan performa olahraga seorang atlet.

Meskipun peningkatan keterampilan mental diikuti oleh peningkatan kepercayaan diri semua perenang Ragunan, namun tiap perenang merasakan latihan mental tertentu yang paling berperan dalam meningkatkan kepercayaan dirinya. Hal ini sangatlah wajar karena pengalaman yang melibatkan aktivitas dan tubuh seperti atlet bersifat sangat individual (individual differences). Selain memiliki karakteristik yang berbeda-beda, pengalaman atlet juga dipengaruhi oleh situasi spesifik yang sedang dihadapinya (Stelter, 2003).

Empat dari tujuh perenang menyatakan bahwa relaksasi merupakan latihan mental yang paling berperan dalam meningkatkan kepercayaan dirinya. Relaksasi menimbulkan efek otomis yang dapat meredakan kecemasan. (Wolpe, 1982). Stevens dan Lane (2001) menjelaskan bahwa prosedur relaksasi dapat membuat seseorang lebih mampu mengendalikan suasana hatinya, sehingga atlet tersebut tidak mudah dipengaruhi oleh gangguan-gangguan emosional sesaat yang mungkin muncul dari dalam dirinya sendiri maupuan dari luar dirinya. Prosedur relaksasi dapat membantu atlet untuk mengubah perilakunya menjadi lebih baik di dalam maupun di luar gelanggang olahraga (Mohr, 2001).

Sementara itu, tiga perenang lainnya menyatakan bahwa visialisasi merupakan latihan mental yang paling berperan dalam meningkatkan kepercayaan dirinya. Penelitian Howe (1991) menunjukkan bahwa latihan visualisasi atau imagery secara konsisten berhasil meningkatkan selfefficacy. Selain itu, dalam proses visualisasi atlet juga mengembangkan pola pikir positif. Dengan membayangkan diri dalam lingkungan yang baik, maka seseorang dapat memperoleh lebih banyak kemudahan dalam bertindak (Fanning, 1988).

\section{Kesimpulan dan Saran}

Hasil penelitian ini menyimpulkan bahwa intervensi berupa pelatihan mental efektif dalam meningkatkan kepercayaan diri yang dimiliki atlet renang Sekolah Ragunan. Selain itu, diketahui pula bahwa relaksasi dan visualisasi menjadi bentuk latihan yang dianggap paling berperan dalam meningkatkan kepercayaan diri atlet renang Ragunan.

Penelitian selanjutnya perlu menyesuaikan pemberian bentuk maupun porsi keterampilan mental untuk masing-masing atlet. Sehingga program latihan mental lebih bersifat individual, fokus, dan terarah. Penelitian serupa juga dapat diarahkan pada lintas cabang olahraga lainnya, sehingga data yang diperoleh lebih kaya. Pentingnya tahap pendidikan tentang latihan mental, hendaknya menjadi perhatian berbagai pihak. Sementara 
saat ini jumlah tenaga psikolog atau konsultan olahraga masih terbatas, maka perlu ditingkatkan jumlah tenaga yang dapat memberikan pelayanan psikologi di bidang olahraga.

\section{Daftar Pustaka}

Anshel, M.H. (1991). Dictionary of the sport and exercises. Champaign, IL: Human Kinetics.

Azwar. S. (1992). Reliabilitas dan validitas. Yogyakarta : Sigma Alpha.

Bhamri, E., Dhillon, P.K., Sahni, S.P. (2005). Effect of psychological interventions in enhancing mental thougness dimensions of sport persons. Journal of the Indian academy of applied psychology, 31, 65-70.

Bandura, A. (1997). Psychological modeling, conflicting theories. Chicago: Atherton, Inc.

Baron, R.A., Bryne, D. (1994). Social psychology : Understanding human interaction. Boston : Allyn and Bacon.

Deaux, K., Dane, F.C., Wrightsman, Lawrence, S., dan Siegelman, C.K. (1993). Social psychology in the 90s. California : Brooks/Cole Publishing Company.

Deputi Bidang Peningkatan Prestasi Olahraga, Kementerian Pemuda dan Olahraga. (2011)

Eversheim, U., Bock, O. (2002). The role of precues in the preparation of motor responses in humans. Journal of motor behavior. 34 (3), 271-276.

Fanning, P. (1988). Visualization for change. California : New Harbinger.

Feltz, D.L., Short, S.E., Sullivan, P.P., (2008) Self-efficacy in sport. USA : Human Kinetics, Inc.

Fletcher, D., Hanton, S. (2001). The relationship between psychological skills usage and competitive anxiety responses. Psychology of sport and exercise. 2 (2), 89-101.

Goldfried, M.R., Trier, C.s., (1974). Effectiveness of relaxation as an active coping skill. Journal of abnormal psychology. 83 (4), 348355.

Gunarsa, S., Soekasah, M., Satiadarma, M.P. (1986). Psikologi olahraga prestasi. Jakarta : Pustaka Obor.

Horn, T.S. (2008). Advances in sport psychology. $3^{\text {rd }}$ edition. Ohio : Human Kinetics, Inc.

Howe, B.L. (1991). Imagery and sport performance. Journal of sport medicine, 11, 1-5.

Loehr, J.E. (1982). Mental thougness training for sports. New York : Forum Publishing Company.

Mohr, C. Learning how to be a good sport : An intervention aimed at increasing sportperson-like behavior. Behavior change, 18 (4), 236240.

Morrison, K.A. (1999). The examination of state sport-confidence of secondary school boys and girls participating in coeducational and gender separated physical education class. Thesis. Canada : Faculty of Education McGill University.

Nasution, Y. (2009). Latihan mental bagi atlet pelajar. Jakarta : Pusat Pengembangan Kualitas Jasmani, Sekretariat Jenderal Departemen Pendidikan Nasional.

Porter, K., Foster, J. (1990). Visual athletics. Dubuque, IA : Wm C.Brown.

Rushall, B.S. (2008). Mental skills training for sports. Fourth edition. California : Spring Valley.

Satiadarma, M.P. (2000). Dasar-dasar psikologi olahraga. Jakarta : Pustaka Sinar Harapan.

Satiadarma, M.P. (2006). Integrasi self-hypnosis dan visualisasi sebagai faktor pada atlet untuk mencapai penampilan puncak. Disertasi (ringkasan). Depok: Fakultas Psikologi Universitas Indonesia.

Savelbergh, G.J., Van der Kamp, J. (2000). Information in learning to co- ordinate and control movements : Is there a need for specificity of practice? International journal of sport psychology, 31 (4), 467484.

Setyobroto, S. (2005). Psikologi olahraga. Jakarta : Percetakan Universitas Negeri Jakarta.

Shone, R. (1984). Creative visualization: how to tap your hidden potential. London : Thorsons.

Stelter, Reinhard. 2003. Future Perspectives for a Possible State-of-theArt in Sport and Exercise Psychology. Journal of sport psychology. Belanda : University of Copenhagen.

Stevens, M.J., Lane, A.M. (2001). Mood-regulation strategies used by athletes. Athletic insight: Online journal of sport psychology. 3 (3).

Townsend, C. (2005). Training for swimmers. Australia : Bellissima Publishing.

Vealey, R.S. (1986). Conceptualization of sport-confidence and competitive orientation : preliminary investigation and instrument development. Journal of sport psychology. 8, 221-246

Vealey, R.S., Hayashi, S.W., Giacobbi, P., \& Garner-Holman, M. (1998). Sources of Sport-Confidence : Conceptualization and Instrument Development. Journal of sport and exercise psychology, 20, 54-80.

Weinberg, R.S., Gould, D.G. (1995). Foundation of sport and exercise psychology. USA : Human Kinetics.

Wolpe, J.M., (1982). The practice of behavior therapy. Third edition. New York : Pergamon Press. Wawancara Pelatih Renang Sekolah Ragunan. (Desember 2011). Wawancara Atlet Renang Sekolah Ragunan. (Desember 2011).Rusman. 2012. Model-Model Pembelajaran: Mengembangkan Profesionalisme Guru Edisi Ke Dua. Jakarta: Rajawali Pers.

Sanjaya, Wina. 2006. Strategi Pembelajaran. Jakarta: Media Prenada.

Singarimbun, Masri. 2006. Metode Penelitian Survai, Jakarta: LP3ES Indonesia.

Sudjana, Nana. 1989. Cara Belajar Siswa Aktif dalam Proses Pembelajaran. Bandung: Sinar Baru.

Sudjana, Nana. 2010. Penilaian Hasil Proses Pembelajaran, Bandung: PT. Remaja Rosdakarya.

Suherman, Adang. 2009. Model Pembelajaran Pendidikan Jasmani: Alternatif Pengembangan dan Implementasi Model Pembelajaran dalam Pengajaran Penjas, Bandung: FPOK UPI.

Sukintaka. 2004. Teori Pendidikan Jasmani, Bandung: Nuansa. 